\title{
Correction to: Disturbance in Mineral Nutrition of Fenugreek Grown in Water Polluted with Nanosized Titanium Dioxide
}

\author{
Takwa Missaoui $^{2,3} \cdot$ Moêz Smiri $^{1,2} \cdot$ Hajer Chemingui $^{2} \cdot$ Zahrah Alhalili $^{1} \cdot$ Amor Hafiane $^{2}$
}

Received: 4 January 2021 / Accepted: 4 January 2021 / Published online: 24 February 2021

○) Springer Science+Business Media, LLC, part of Springer Nature 2021

\section{Correction to: \\ Bulletin of Environmental Contamination and Toxicology https://doi.org/10.1007/s00128-020-03051-0}

In the original version of the article, inadvertently two different author names "Hajer Chemingui" and "Zahrah Alhalili" are mixed together. This has been corrected with this erratum.

The original article has been corrected.

Publisher's Note Springer Nature remains neutral with regard to jurisdictional claims in published maps and institutional affiliations.

The original article can be found online at https://doi.org/10.1007/ s00128-020-03051-0.

Takwa Missaoui

takwa.missaoui@certe.rnrt.tn;

Takwamissaoui728@yahoo.com

1 Faculty of Arts and Sciences Sager Campus Boys, Shaqra

University, Shaqraa, Riyadh, Saudi Arabia

2 Laboratory of Water, Membranes and Environment Biotechnology (LEMBE) Technopole of Borj Cedria (CERTE), 2050 Hammam-Lif, Tunisia

3 National Agronomy Institute of Tunis, 43 Avenue Charles Nicolle, 1082 Tunis, Tunisia 